\title{
慢性関節リウマチ患者の頸椎レ線変化について
}

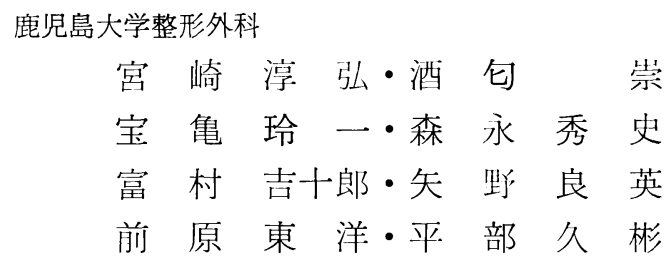

\section{Abnormal Findings of The Cervical Spine in Rheumatoid Arthritis}

By

\author{
A. Miyazaki, T. Sakou, R. Houki, H. Morinaga, \\ K. Tomimura, T. Maehara, Y. Yano, \\ H. Hirabe, H. Kawamura \& T. Osako \\ Department of Orthopaedic Surgery, Faculty of Medicine, \\ Kagoshima University. (Director: Professor A. Miyazaki)
}

\begin{abstract}
X-ray examination of the cervical spine were performed on twenty-one hospitalized patients and fourty-two ambulatory patients complaining of neck pains with rheumatoid arthritis. Abnormal atlanto-odontoid separation was found in twenty-four patients and pseudo-basilar impression in thirteen. One of them showed maximum upward transposition of the dens of $10 \mathrm{~mm}$ above Macgregor's baseline. In addition subluxation of subaxial levels, endoplate erosions and erosions of apophyseal joint were found frequently at the level of $\mathrm{C}_{2-3}$ to $\mathrm{C}_{4-5}$. Atlantoaxial posterior fusion by $\mathrm{R}$. W. McGraw was carried out on a case suffering from severe occipital pain and trigeminal neuralgia associated with sublu xation of the atlano-axial joint on March 151974 . Three months after operation she had relieved of occipital pain and hyperalgesia on limb and trunk.
\end{abstract}

慢性関節リウマチ患者の頸椎罹患の頻度はたかく， レ線上, 钼椎に種々の変化がみられることは多くの報 告によりよく知られているととろである．また環軸椎 転位による死亡例の 報告もある，慢性関節りウマチ (RA) 患者の頸椎レ線変化については, Sharp, Martel, Bland らの報告があり, その特徵として環軸椎亚 脱臼, 頸椎の多発严脱臼, 上位頸椎における骨棘形成 のない椎間狭小, 侵蝕, 後方椎間関節炎, 頭蓋底陥入 (pseudobasilar impression)などをあげている.

今回われわれは RA 患者の頸椎変化をレ線学的に検 討し, 環軸椎覀脱白著明で激しい後頭部痛を訴えた症 例に環軸椎後方固定術を行なった 1 例を経験したので 若干の文献的考察を行ない報告する.

\section{調查対象患者}

RA にて鹿児島大学整形外科および関連病院にて外 来治療あるいは入院中の症例で钼部に何らかの愁訴を 有するものを対象とした，入院中のもの 21 例, 外来通 院中のもの 42 例, 計 63 例で, その内訳は男性 6 例, 女性 57 例であった。年令は 20 才より 75 才におよび 平均 50.7 才で, 50 才以上の症例が過半数を占めてい る. 羅患年数は 1 年より 23 年におよび平均 8.0 年で 15 年以下の症例が大部分を占めている。病型は definite 12 例, classical 51 例で, Stage 分類では Stage I, II 各 10 例， III 18 例，IV 25 例で， III，IV 亿属する 症例が多かった。 


\section{成}

\section{績}

環軸関節亜脱曰を頸椎屈伸時における環椎前弓後面 と菌突起前面との距離を測定し，てれを ADI とし， $3 \mathrm{~mm}$ 以上を異常所見とした. 亜脱臼の症例は 24 例 (38\%) にみられた。 その内訳は $3.0 \sim 3.9 \mathrm{~m} \mathrm{~m} 10$ 例, $4.0 \sim 4.9 \mathrm{~mm} 8$ 例, $5.0 \sim 5.9 \mathrm{~mm} 5$ 例, $6.0 \sim 6.9$ $\mathrm{mm} 1$ 例で, 多くは $3.0 \sim 4.9 \mathrm{~mm}$ の間にあり, 最 高 $6.5 \mathrm{~mm}$ であった．とれを䍜患年数との関係につ いてみると, 5 年以下 29 例中 5 例 (17\%), 5 10 年 18 例中 9 例 $(50 \%), 10 \sim 15$ 年 13 例中 8 例 (62\%), $15 \sim 20$ 年 4 例中 2 例 $(50 \%)$ であり， 5 年以降に急 速に増加傾向がみられる. Stage との関係でも Stage I 10 例中 1 例 $(10 \%)$, Stage II 10 例中 4 例 (40 $\%)$, Stage III 18 例中 6 例 $(33 \%)$, Stage IV 25 例 中 13 例 $(52 \%)$ と Stage の進行とともに増加の傾向 がみられ, さらに ADI の值も Stage の進行とともに 増加の傾问がみられる（図1). 次に歯突起高位につ いてみると. 米突起尖端が Macgregor's baseline を $4.5 \mathrm{~mm}$ 以上を越えるものを異常所見とした. 異常は 13 例 (21\%) あり，4.5〜 5.0 m m 6 例, $5.1 \sim 6.0$ $\mathrm{mm} 0$ 例, $6.1 \sim 7.0 \mathrm{~mm} 3$ 例, $7.1 \sim 8.0 \mathrm{~mm} 2$ 例, $8.1 \sim 9.0 \mathrm{~m} \mathrm{~m}, 9.1 \sim 10.0 \mathrm{~mm}$ 各1例であった（図 2. a ). 歯突起高位異常と䍜患年数の関係をみると, 5 年以下 24 例中 2 例 $(8 \%), 5 \sim 10$ 年 18 例中 6 例 (33.3\%)，10〜15年 13例中 4 例（30.7\%）で櫵患 年数 5〜15 年のものに多いようである. 次に Stage との関係について述べると, Stage I では 10 例中 1 例 $(10 \%)$, Stage II では 10 例中 1 例 (10\%), Stage III では 18 例中 3 例 (16.7\%), Stage IV では 25 例中 8 例 (32\%) と Stage の進行につれて増加している. その他の所見では，歯突起の erosion が 22 例 (35 \%) あり，歯突起が著しく細小化したものや突起後面 に hook erosion の形成がみられた症例もあった（図 2 ， b ). また軸椎外側塊の erosion は 14 例 (22\%) で, 外側環軸関節や環椎後頭関節部の狭小化や強直を 思わせる症例も多く認められた．次に軸椎下位の異常 所見を述べると椎間関節の 異常（もうろう化や erosion) が 50 例 $(79 \%)$ あり, $\mathrm{C}_{2-3}$ 間に多く, 不安定 椎は 46 例 $(73 \%)$ で $\mathrm{C}_{4-5}$ 間にズレが多発している. 中には多椎間にわたりズレがみられ，step ladder を 形成する症例も 2〜3 みられた：椎間関節軟骨の erosionは27例 (42.9\%) であった。

\section{ADI と罹患年数}

\begin{tabular}{|c|c|c|c|c|c|}
\hline & 5 & 10 & 15 & 20 & 25 年 \\
\hline $3.0>$ & 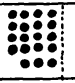 & $\begin{array}{l}: \\
: \\
:\end{array}$ & 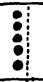 & 8 & 8 \\
\hline $3.0 \sim 3.9$ & : & $:$ & 8 & $\bullet$ & \\
\hline $4.0 \sim 4.9$ & & 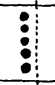 & $:$ & $\bullet$ & \\
\hline $5.0 \sim 5.9$ & $\bullet$ & $\cdot$ & 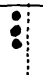 & & \\
\hline $6.0 \sim 6.9$ & & $i$ & $\bullet$ & & \\
\hline
\end{tabular}

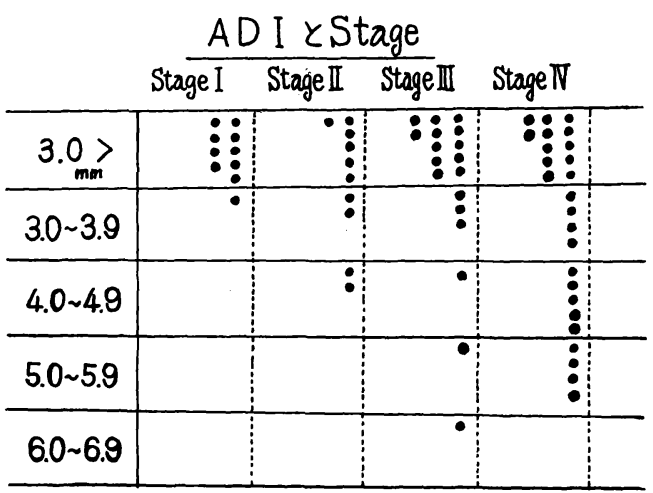

図 1

臨床症状との関係について述べると, 亜脱臼群, 非 脱曰群とも後頭部痛および頸・肩に疼痛のみられる症 例が多いが，亜脱臼群に $76 \%$ 高率に後頭部痛が出 現している. 腱反射異常や知覚障害などの脊㵦症状と 考えられる症状は, 非脱四群 $21 \%$, 亜脱臼群 $28 \%$ と あまり差異がみられなかった（扫 3 ).

最後に環軸椎後方固定術を行った 1 例を紹介する. 症例. $29 才$ 才, 女性.

昭和 37 年 11 月頃 (17才時) 右関節痛にて発症, progressive type の経過をたどる. 初発時よりほと んどの期間 steroid の1〜2 錠を連用していた. 昭和 46 年から 48 年にかけて金療法を受け，副作用のため 中止するまで $1000 \mathrm{mg}$ 使用した。昭和 48 年 4 月頃よ り ACTH 療法にて steroid を離脱し, 昭和 48 年 9 月左肘関節滑膜切除術を受けた。

初䛦時間もなくより時々項部痛があり，昭和 47 年 頃より疼痛は増強し, 頸椎運動制限, 左上肢シビレ感 などを伴なうようになった。昭和 49 年 2 月環軸椎要脱 白を指摘され当科入院. 主な入院時所見としては, 靧 


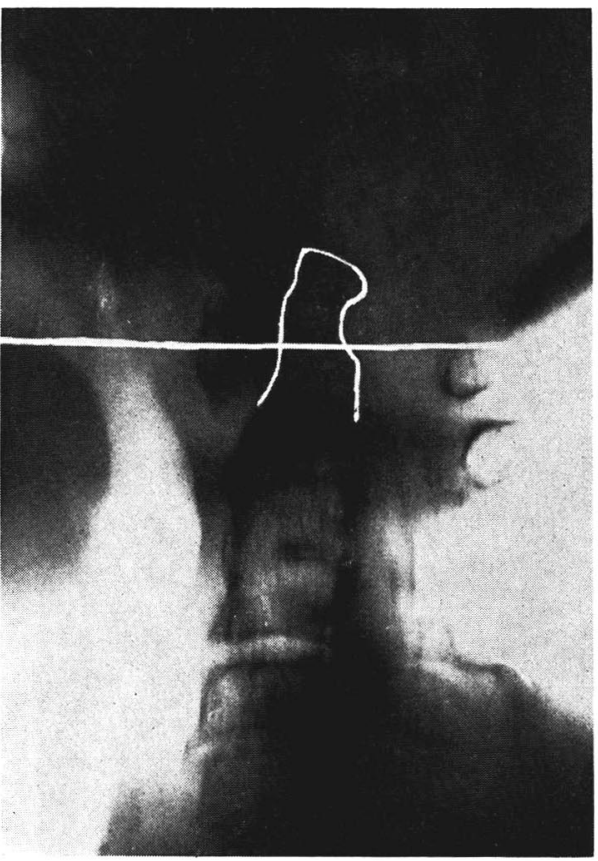

a . 歯突起高位 $(10 \mathrm{~mm})$

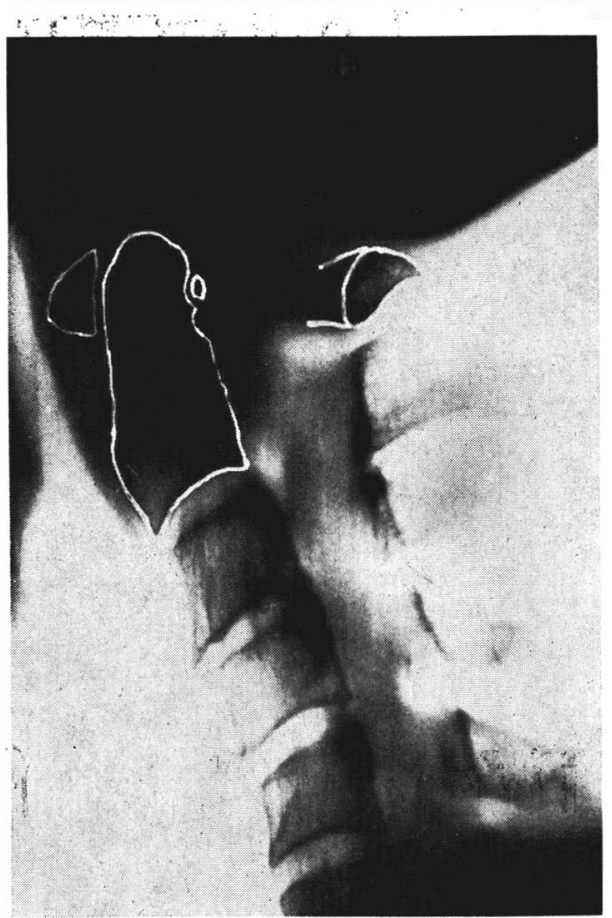

b. hook erosion と osteochondritis dissecans 様の遊離骨片

図 2

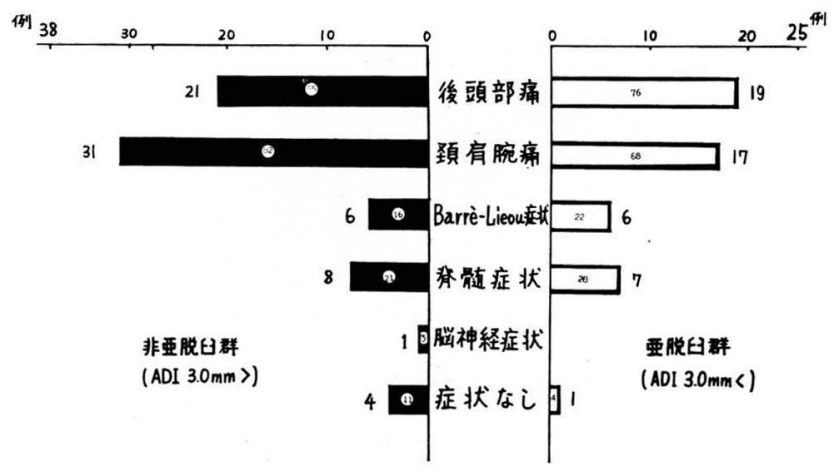

図 3 環軸関節亚脱曰 (ADI) と臨床症状（グラフ内の数字は％)

保存的療法で症状の改善全く認められず, 激しい後頭部痛が持続するために, 昭和 49 年 3 月 19 日 McGraw 法により環軸椎 後方固定術を施行した. 術後 2 週より莖椎 固定装具を着用し歩行を許可した．現在， 術後 3 力月を経過しているが術直後より疼 痛, 腱反射元進, 知覚過敏の消失をみとめ 良好な経過をとっている。

考按

RA で頸椎に変化をきたすととはSharp らの報告以来多くの報告がなされている。

Conlon らは 333 例のうち 295 例 (88\%)

部および後頭部痛, 顔面・側頭部および前額部へ放散 する疼痛, 両肩・両上肢への放散痛があり, 両上下肢 の腱反射軽度六進し, 両上下肢全域の知覚過敏を認め る. 企図振せんもみられる. 頸椎運動性は伸展 $30^{\circ}$, 屈曲 $60^{\circ}$, 左方回旋 $25^{\circ}$, 右方回旋 $20^{\circ}$, 左方側屈 $20^{\circ}$, 右方側屈 $25^{\circ}$ と著明に制限, Spurling's test およ び Eaton's test 両側強陽性. ADI 6 mm であった. に頸部症状がみられ，167例（50\%）に RA による 特徵的なレ線変化を認めている. そして平均 6 年の経 過を観察し頸椎変化の進行, 特に環軸椎覀脱臼の頻度 が著しく増加するととを述べている．RA の特徽的な 頸椎変化である環軸椎亜脱臼の頻度については報告者 によりかなりの相違がみられ，18\%から $70 \%$ \%值が 報告されているが，われわれの症例では $38 \%$ と比較 
的高率にみられた。環軸椎严脱臼と罹患年数との関係 については, Conlon らは否定しているが，七川らは 関係のみられることを報告している，われわれの症例 では明白な関係がみられ，また Stage の進行につれ て增加の傾向がみとめられた。

環軸椎亜脱臼の程度の進行により後頭部痛や脊㖪障 害の発現した症例に対して, 環軸椎の固定が行なわれ ているが，ての際できるだけ後頭骨まで固定せずに回 旋の運動機能を温存するととが重要なととであろう. 観血的に固定を行なうか否かについては議論があり， stage の進行した症例の中には亜脱臼を残し強直がお こり，症状の消失をみた症例をわれわれも経験してお り，また保存的に Thomas のカラ一固定により症状 の軽減をみた症例も多いので, 術前の充分な経過観察 と手術適応に関しての検討を行なうことが必要であろ う.

\section{参考文献}

1) Sharp, J. et al.: Ann. rheum. Dis. 17 : 303, 1958.

2) Sharp, J. et al.: Ann. rheum. Dis. 20:47, 1961.

3) Martel, W: Am. J. Roent. 86: 223, 1961.

4) Bland, J. H.: Arch. intern. Med. 112: 892, 1963.

5) Conlon, P. W. et al.: Ann. rheum. Dis. $25: 120,1966$.

6) Isdale, I. C. and Conlon, P. W.: Ann. rheum. Dis. $30: 387,1971$.

7) Sweetnam, R.: Ann. rheum. Dis. $29: 330$, 1970.

8) Davis, F. W. et al.: Ann. intern. Med. 35 : 451, 1951.

9) Webb, F. W. S. et al.: Br. med. J. 2 : 537, 1968.

10) Cregen, J. C. F.: Ann. rheum. Dis. 25 : 242, 1966.

11) Crellin, R. Q. et al. : J. Bone Jt. Surg. 52B : 244, 1970.

12) McGraw, R. W. et al.: J. Bone Jt. Surg. 55-B : 482, 1973.
13）七川5: 臨床整形外科. 3:15, 1968.

14）山本 5 : 整形外科と災害外科. $20: 179,1971$.

15）所 5 : 臨床整形外科. $8: 551,1973$.

16）伊藤：第18回日本リウマチ学会口演, 1974 .

質 問北里大学 山本 真 上位頸椎の高厚の変化は mutilans 型 RA に多い とされていますが, 先生の症例でもそういう傾向があ りましたか?

回答兟览島大学整形外科 宝亀 玲一

1. 山本先生に対する回答

mutilans type の症例はありませんでした。

2 . 木村先生に対する回答

レ線変化の程度から手術の適応を決定するととはむ ずかしい. われわれの手術症例の場合激しい疼痛, 脊 葡症状の存在, 保存的治療の無効, 患者自身の社会復 帰に対する意欲などを考慮し手術にふみきった。

\section{買 問 熊本大学整形外科 木村 千仪}

上位頸椎変化があって神経症状がどの程度の場合に 固定術を行なうか.

回答鹿児島大学整形外科 酒公 崇 今回調査した症例の中に, 環軸椎の強直例で頸部症 状の寛解している症例がみられた，従ってまず保存的 治療法を允分に行った上で経過を観察し，症状改善が みられず，日常生活に支障を来たす症例の場合には， $\mathrm{C}_{1-2}$ の後方固定術を行った方がよいと考える.

\section{意 見長崎大学 鈴木 良平}

リウマチによる高度の疼痛を有する環軸関節の亜脱 臼に対しtransoral に固定術を行なった経験がある. 幸いに好結果をえたが，感染の心配もあり，顎関節の 動きも覀い例もあるのでリウマチに対しては後方固定 の方が安全と考える. 